\title{
NEW METHODS IN THE RESEARCHING OF OLD DUBROVNIK'S LITERATURE
}

Irena Arsić ${ }^{1}$

Faculty of Philosophy, University of Nis, Republic of Serbia

\author{
Review paper
}

Received: 27.07 .2016

Accepted: 08.09.2016

\begin{abstract}
The research of the Ancient Dubrovnik's literature had primarily began by its biographers; afterwards significant documents that had been found in the Dubrovnik's archive made possible to the researchers to give immense contributions in this field. The 21 st century brought, in the area of the historiography especially, new approaches toward research of the renaissance and baroque literature of the Ancient Dubrovnik. New findings in Marin Držićs biography, as well as research of the social status in Dubrovnik, especially of its aristocracy have made possible to apply the new methods in studies of the works written during the time of the Renaissance, and above all the comedies. Additionally, the forming of the Dubrovnik's myth, which has been constructed for centuries by the writers of the Old Republic provides new and more intellectual view on their literary contribution.
\end{abstract}

Key words: Dubrovnik, renaissance, baroque, new historicism, subversive literature

\section{INTRODUCTION}

To begin with, the biographers and historians from Dubrovnik (Ragusa) had an aim to preserve the works of their contemporaries. Therefore, they often assembled collections of the biographies of the authors or just notes with short description of the biographic and bibliographic data; these anthologies had been evaluated by their writers, by studying characteristics such as their religious order, universities which they attended, areas of expertise, but also in the chronological sense. Plethora of these records are not reliable and are wrongly quoted, but the significant result is the enormous biographic and bibliographic material regarding the literature works in the Ancient Dubrovnik for centuries.

During the $19^{\text {th }}$ century, this important corpus became the material for the first history of the Dubrovnik's literature made by Italian Francesco Maria Appendini. Appendini, professor from Dubrovnik,in the work Notizie istorico-critiche sulle antichita, storia e letteratura de' Ragusei (Appendini, 18021803) had presented the old Dubrovnik's literature as a whole, which had opened the door for the future investigations in this field (Stanojević, 2013). The end of the $19^{\text {th }}$ century brought the revolutionary discover in the terms of the research of the literature of Dubrovnik. During its research on the field of history of the Balkans, above all history of the Serbs, Czech historian Konstantin Jireček (Jireček, 1899) discovered important archive documents significant for the history of the Dubrovnik's literature (Jireček, 1897, 1899). His finding brought new possibilities in the terms of abovementioned literature studies; this, later on, was accepted by the numerous prestigious philologists who had discovered in the Dubrovnik`s archive essential materials regarding to the biographies and works of the authors of the Ancient Dubrovnik`s literature.

\section{${ }^{1}$ Correspodence to:}

Irena Arsic, PhD, Faculty of Philosophy, University of Nis, Republic of Serbia

Phone: +381648013397

e-mail: irena.arsic@filfak.ni.ac.rs 
One of them was Pavle Popović, who defined in his work (published in 1910), new research methods of Dubrovnik`s literary tradition (Popović, 1910).

From mid-twentieth, Miroslav Pantić had been studying the literature of the Ancient Dubrovnik, adopting the methodology used by Pavle Popović. However, in his inauguration speech held in SASA in 1984 (Pantić, 1984), Pantić without any previous warning, began the new methodology of the research of the Dubrovnik's literature. For instance, while working in the Dubrovnik's archive, he discovered the historical prototypes of the 16th century Dubrovnik in work Novela od Stanca by Marin Držić; this analysis brought the new interpretation of the play. To sum up, then it was new, and now it is current way in research of the renaissance literature, new historicism and cultural materialism (Greenblatt, 1988).

Marin Držić, the greatest playwright from Dubrovnik, presents one of the most important figures in the Ancient Dubrovnik's literature, next to the baroque poet Ivan Gundulić. Therefore, the examination of Držić's opus was the model which was utilized for all other renaissance writers; consequently, new studies regarding his work, reflected also to the new studies in the renaissance literature from Dubrovnik. As a result, the $21^{\text {th }}$ century brought improved accesses to the research of the Ancient Dubrovnik's literature.

The interpretation of Držić's "conspiracy letters", discovered in 1930s, for a long period was the main theme of the polemic discussions. However, in 2007 in Florence, was identified sixth conspiracy letter discovering the existence of the seventh letter, as well, thusrevealing correspondence between the miserable Ragusian and Cosmo Medici and his son Francesco who was duke at that time. Additionally, it was revealed that Držić was held and examined by the Florentine police, which proves that his resistance towards Dubrovnik`s government was not easily taken by the Florentine authorities (Kunčević, 2007). This revelation was spectacular, because it brought into question all earlier conclusions about author's personality, biography and literary opus.

On the results of this investigation are linking the researches of two historians, Nenad Vekarić and Stjepan Ćosić, who, at the beginning of the 21 st century, have observed certain divisions of the Dubrovnik's nobility, which had been systematically expressed throughout the centuries(Ćosić and Vekarić, 2005; Vekarić, 2009).Thus, then oblemen from Dubrovnik were also writers: there were, among them, those whose literary works had surpassed the level of amusement, which was characteristic of Ragusian understanding of the literature. Consequently, abundance of literary pieces now had to be interpreted differently; to be more precise, in accordance with social status of the authors in this divided aristocratic society.

Firstly, regarding to Marin Držić himself, this methodology lead to the so-called "return" of the poets to Dubrovnik, by its justification and explanation of the political misunderstandings in Florence. What's more, our author with his political attempt, was a part of secret group of the Dubrovnik`s aristocracy, always between the idea of independence and real independence, known today as a controlled independence (which it really was at that time). Regarding to Vekarić and Ćosić, in the terms of the detailed analysis of Dubrovnik's royalty, Držić was an envoy of one out of the two influential noble parties of that time.

Secondly, more direct influence of this division can be found in the work of Ivan Gundulić, the baroque poet. For instance, the allegory of his pastoral Dubravka was interpreted as a critique of his time which had closer explained his membership in the clan sorboneza. Additionally, his epic Osman has the ideological interpretation in criticism of the monarchic government opposed to the ideal, aristocratic parliamentary one, which had during the centuries, been reigning n Dubrovnik.

Thirdly, it is evident that the elements for the new approach to the Ancient Dubrovnik's literature are coming from the field of the historiography, which is neither unusual, nor inappropriate for the city of Dubrovnik. People of The City understand their literature works as duties to their country, i.e. liberty. Therefore, historian Lovro Kunčević with that aim wrote the literary piece Mit o Dubrovniku: diskursi o identitetu renesansnog grada (Kunčević, 2015). Kunčević, the discoverer of the lost Držić`s letter, is the author of the book which has opened the new perspective for the researchers of the Dubrovnik's literature.For instance, during his elaborate research of the literary and unliterary Dubrovnik's tradition, he discovered that writers, under a big influence of the authorities, gave the remodeled image of The City. Consequently, they had created several myths of Dubrovnik which Kunčević separated in groups: myth of origin, state and borders.

Dubrovnik is a renaissance town, and similar to its opponent Venice, without antique tradition. 
Contrary, ancient heritage was provided by binding with nearby antique Epidaurus, today known as Cavtat and with its legacy: the Christian church and patrician origin. Therefore, "new" Dubrovnik, (contrary to "old" Cavtat) received its legitimacy as a church community with a right of its own archdiocese and as aristocratic parliamentarian republic, which royalty considered as their private property The Slav origin of the population (Pavlimir legend) was fulfilled with the Roman element which finally completed myth about Dubrovnik.

Differently from other renaissance cities, in Dubrovnik significant part presented the statehood myth due to its complexity during the centuries. For instance, from 19th century Dubrovnik was under a rule of Venice, Austrians and the Ottoman Empire.???.

Forming of The City`s legend as the most crucial border state, demanded gathering of the most intelligent Ragusian minds. Despite its difficult position, situated between the Ottoman Empire and Dalmatia which was under the Venice rule, as well as among the Catholic and Orthodox Church, Dubrovnik succeed to benefit from it. Therefore, Dubrovnik became diplomatic state which had found itself for many times between the different opponents. That is the reason why, its historians, writers and diplomats are often justifying their acts due to the border position among different religions and cultures.

The book Mit o Dubrovniku: diskursi o identitetu renesansnog grada by Lovro Kunčević presents innovative view on written and unwritten tradition of Republic of Dubrovnik. For that reason, the most valuable literary pieces from the Ancient Dubrovnik's literature had to be interpreted from the perspective of its myth`s legacy.

New interpretations in research of the Dubrovnik's literature are bringing it closer to historiography and far away from aesthetic. This type of creativity was not unusual for Ancient Dubrovnik`s literature which was constantly observed by its authorities. To conclude, all this opens the new possibilities for the new historical analysis of this centuries old literature.

\section{REFERENCES}

Appendini, F. M. (1802-1803). Notizie istorico-critiche sulle antichita, storia e letteratura de' Ragusei. I-II. Ragusa: Antonio Martecchini

Ćosić, S. \& Vekarić. N. (2005). Dubrovačka vlastela između roda i države: salamankezi i sorbonezi. Zagreb-Dubrovnik. Hrvatska akademija znanosti i umjetnosti Zavod za povijesne znanosti u Dubrovniku

Greenblatt, S. (1988). Shakespearean Negotiations: The Circulation of Social Energy in Renaissance England. Berkley-Los Angeles. The University of California Press

Jireček, C. (1897). Der ragusanische Dichter Šiško Menčetić. Archiv für slavische Philologie. XIX

Jireček, C. (1899). Beiträge zur ragusanischen Literaturgeschichte. Archiv für slavische Philologie. XXI

„Ipak nije na odmet sve čuti": medičejski pogled na urotničke namjere Marina Držića. Anali Zavoda za povijesne znanosti HAZU u Dubrovniku. XLV:9-46.

Kunčević, L. (2015). Mit o Dubrovniku: diskursi o identitetu renesansnoga grada. Zagreb - Dubrovnik. Hrvatska akademija znanosti i umjetnosti - Zavod za povijesne znanosti u Dubrovniku.

Popović, P. (1910). Noviji metodi u proučavanju dubrovačke književnosti. Srpski književni glasnik. XXV:833-841.

Stojanović, P. (2013). Književni istoričar Frančesko Marija Apendini. Beograd:: Ars libri

Stojan. S. (2007). Slast tartare. Marin Držić u svakodnevici renesansnog Dubrovnika. Zagreb - Dubrovnik. Hrvatska akademija znanosti i umjetnosti - Zavod za povijesne znanosti u Dubrovniku

Pantić, M. "Veliki smijeh” M.D. u svome vremenu i danas. Glas SANU Odeljenje jezika i književnosti.12:1-16.

Vekarić. N. (2009). Nevidljive pukotine: dubrovački vlasteoski klanovi. Zagreb - Dubrovnik. Hrvatska akademija znanosti i umjetnosti - Zavod za povijesne znanosti u Dubrovniku 